\title{
Anti-Sickling Propensities of Carica papaya (L) Plant's Extracts
}

\section{Meena Sahu, Devshree Verma, K.K. Harris*}

Department of Zoology, Government DB Girls' Post Graduate College, Raipur, 492001, Chhattisgarh, India

Study Area: Raipur, India

Coordinates: $28^{\circ} 30^{\prime} 0^{\prime \prime} \mathrm{N} 53^{\circ} 33^{\prime} 38^{\prime \prime} \mathrm{E}$

Key words: Plant extracts, Stem, Leaf, Seed

This project was approved by the ethical committee of the DB Girls' Post Graduate College, Raipur, C.G., India

\section{Abstract}

Sickle cell disease (SCD) is a genetic disorder and the disease is incurable. The management process solely concentrates on providing relief to the patient during the crisis stage of the disease. In this context, phytochemicals present in the plants with antisickling propensities are widely exploited as a cure. Various plants have been reported to possess antisickling propensities by various authors. The present study attempts to investigate in vitro, the antisickling endeavors (sickle cell reversal and erythrocytic inhibition to a sickled contour) of the leaves, seeds and stem extracts of Carica papaya L. in HbSS blood samples, using phydroxybenzoic acid and phosphate buffer saline as positive and negative controls. The inhibition and reversal activities for different concentrations viz., 0.1 to $10.0 \mathrm{mg} / \mathrm{ml}$ of extracts revealed maximum inhibition activity (IA) of $71.80 \%$ in C.papaya L. leaves in a concentration of $1.0 \mathrm{mg} / \mathrm{ml}$; seeds showed a IA of $68.50 \%$ in a concentration of 2.5 $\mathrm{mg} / \mathrm{ml}$; while the stems showed a IA of $68.33 \%$ in a concentration of $10.0 \mathrm{mg} / \mathrm{ml}$. On the other hand, maximum reversal activity (RA) of $72.43 \%$ in Carica papaya L. leaves in a concentration of $10.0 \mathrm{mg} / \mathrm{ml}$; seeds showed a RA of $65.96 \%$ in a concentration of $10.0 \mathrm{mg} / \mathrm{ml}$; while the stems showed a RA of $62.97 \%$ in a concentration of $10.0 \mathrm{mg} / \mathrm{ml}$.

\section{Introduction:}

Sickle cell disease (SCD) is known to be one of the diseases wrecking most parts of the globe without any discrimination against ethnic or racial standards. Sickle cell disease includes those that produce protuberant medical expressions as seen during sickle cell anemia, sickle cell disease, sickle cell trait and an array of other related haemoglobinopathies (Hartwell et al, 200o, Iyamu et al., 2003). Pathophysiology of sickle cell anaemia, sickle cell disease, sickle cell trait and an array of other related haemoglobinopathies are now known to the scientific community. Due to polymerization of the sickled cells, the red cell membrane loses its functional abilities which result in loss of potassium and water and a corresponding gain of sodium ion. Increased intracellular free calcium occurs during sickling (Brugnara, et al., 1993) resulting in a loss of potassium with accompanying movements of chloride and water. Small blood vessels are blocked by the clumping of sickled erythrocytes, averting blood supply to various organs. The process of de-oxygenation in tissue capillaries causes damage to its endothelium, leading to exudation of plasma into the surrounding soft tissue. This is characteristic of the soft tissue swelling seen in most sickle cell disease patients (Olufunmilayo et al., 2010).

Various reports on the antisickling properties of various plant extract on human erythrocytes are available which is well tabulated in Table-1.

\section{Materials and methods:}

Phytochemical analysis Preparation of Plant extracts: the leaves, stems, and seeds were separately cut into small bits, and air dried on shadow for about a fortnight. After drying they were ground and powdered, with $1 \mathrm{~mm}$ size by using a grinding machine before being subjected to phytochemical screening. Four solvents, ethanol, methanol and chloroform, and petroleum ether were used for the extraction of different parts of the plants based on their increasing polarity. Total $30 \mathrm{~g}$ of the powdered leaves, seeds, and stems of Carica papaya L. were extracted in different solvents in Soxhlet apparatus of $250 \mathrm{ml}$. of each solvent separately concentrated by slow evaporation process for 48 hours (Harborne, 1973). The obtained crude extracts were kept in the closed containers for preliminary qualitative phytochemical analysis. 
Ambient Science, 2019: Vol. 06h(1); 11-15

DOI:10.21276/ambi.2019.06h.1.0a02

Table-1: Plant Species used to recover Sickle Cell Anaemia

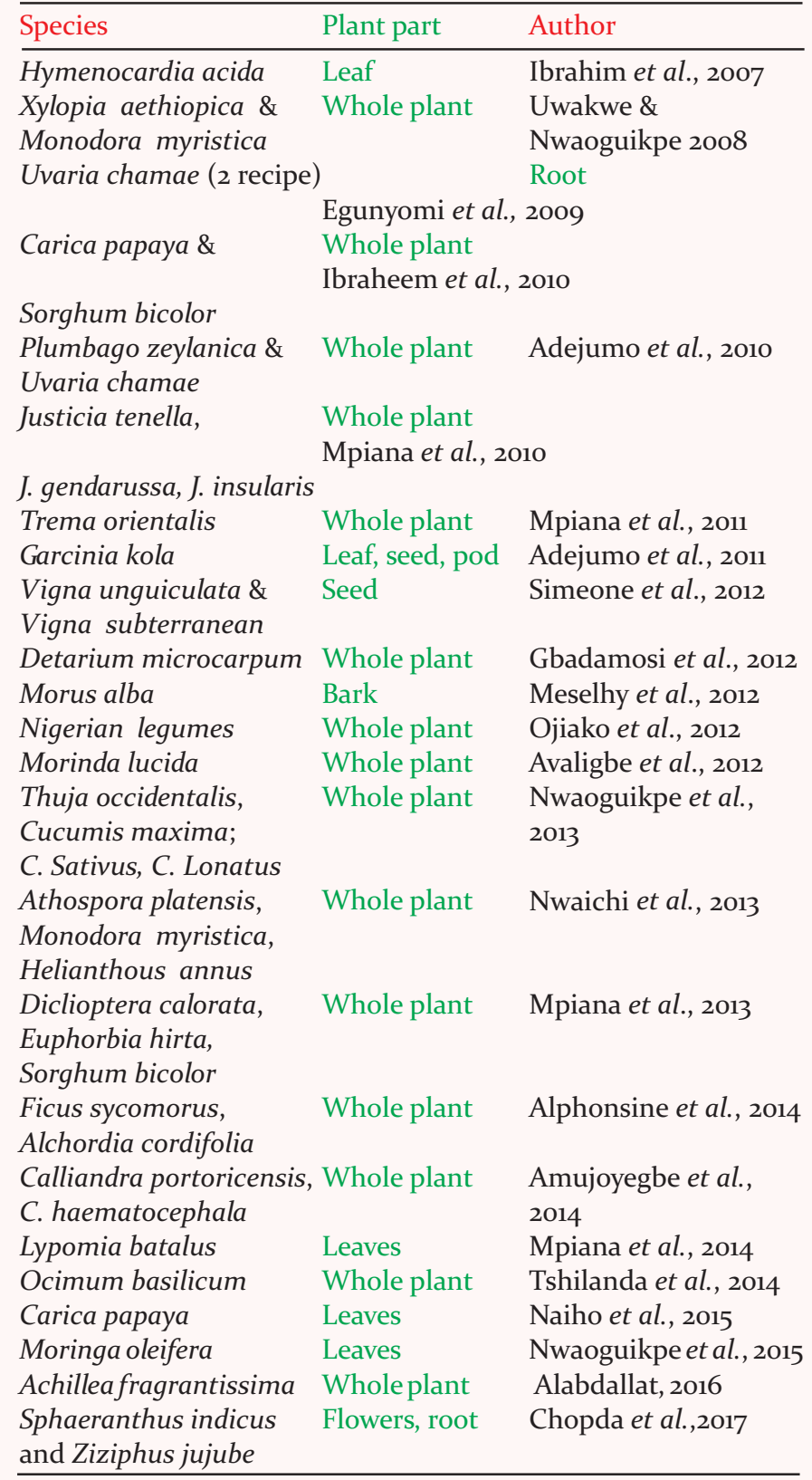

Qualitative Phytochemical Screening: the extracts of each powdered parts of plants were used for phytochemical tests and to identify the constituents, standard procedures were carried out (Trease \& Evans, 1989; Sofowora, 1993). The following phytochemicals: tannin, saponin, reducing sugar, alkaloid, terpenoides, flavonoids, cardiac glycosides anthraquinones and phenols were tested as by following the prescribed methods (Trease \& Evans, 1989; Sofowora, 1993).

Antisickling activity: we used chemicals of analytical graded were methanol, petroleum ether, phosphate buffered saline tablets $\mathrm{pH}$ 7.2, liquid paraffin, formalin, para-hydroxybenzoic acid, paraff in wax, EDTA bottles and distilled water for this study.

Plant sample collection: the fresh leaves, stems and seeds of Carica papaya L. were simultaneously collected from abundant farms, cultivated farms and the open fields in and around Raipur district. After washing properly, they were separately cut into small bits and air dried in shadow for about a fortnight. After drying they were grinded and powdered by using a grinding machine and sieved through a with $1 \mathrm{~mm}$ size mesh. Finally they were preserved in closed air-tight containers for analysis.

Preparation of Extracts: 200 g sample was extracted in Soxhlet apparatus which was described by the method of 1 with petroleum ether $\left(60-80^{\circ} \mathrm{C}\right)$ and aqueous- methanol $\left(60-80^{\circ} \mathrm{C}\right)$ in $1: 3$ as solvents (Ogoda et al., 2002). The prepared extracts were stored at $40 \mathrm{C}$ in freeze in dried form and used for the antisickling activity test. Varying concentrations have been prepared from the dried extracts and used for the antisickling assay which was varied from o.1, 0.5, 1.0, 1.5, 2.0, 2.5, 5.0 and 10.0 mg/ml of leaves, seeds and stem of Carica papaya L.

Collection of blood sample: the blood samples used in the evaluation of the antisickling activity of plants in this study were collected from electrophoresis conf irmed HbSS SCD patients belonging to the age-group 16 to 25 years, of both sexes and it was ensured that they were not taking any allopathic or ayurvedic medications. The samples were drawn in the presence of a qualif ied pathologist. A total of $5.0 \mathrm{ml}$ of fresh blood samples were collected each time by way of vein-puncture in EDTA (Ethylene di-amine tetra acetic acid) anticoagulant tubes and mixed gently to prevent lysing of the red blood cells. In order to confirm their SS nature the above obtained blood samples were first characterized by Hemoglobin electrophoresis on cellulose acetate gel. Blood samples were stored in $\pm 4^{\circ} \mathrm{C}$ temperature.

Inhibition of erythrocytes: for inhibitory activity test 0.2 $\mathrm{ml}$ HbSS sample was pipeted in test tubes in duplicates. Following which, $0.2 \mathrm{ml}$ of phosphate buffered saline solution and $0.2 \mathrm{ml}$ of different concentration of the extracts were added serially. Finally, the mixture was overlaid with $1 \mathrm{ml}$ liquid paraff in wax and incubated in a thermo-stated water bath at $37^{\circ} \mathrm{C}$ for about 4 hours. After incubation $0.6 \mathrm{ml}$ of freshly prepared $2 \%$ sodium meta-bisulphite solution was added under liquid paraff in with the help of a syringe and these mixtures were mixed by rolling the test tubes between the palms of hand carefully. These mixtures were again incubated for about one and half hours in $37^{\circ} \mathrm{C}$ in a thermo-stated water bath. After incubation the liquid paraffin wax was removed with the help of a Pasteur pipette and the resultant mixture was fixed in $3 \mathrm{ml} \mathrm{of} 5 \% \mathrm{v} / \mathrm{v}$ buffered formalin (Cyril-Olutayo et al., 2009).

Reversal of sickled erythrocytes: for reversal of sickled erythrocytes activity tests, $0.2 \mathrm{ml}$ of blood sample was pipeted into test tubes in duplicates. Further, $0.2 \mathrm{ml}$ of phosphate buffered saline solution was added and the mixture was overlaid with $1 \mathrm{ml}$ liquid paraff in wax. A total of 
o.6 ml freshly prepared $2 \%$ sodium meta-bi-sulphite solution was added under liquid paraffin and these mixtures were mixed by rolling the test tubes between the palms of hand carefully, after that they were incubated in a thermo-stated water bath at $37^{\circ} \mathrm{C}$ for $1 \frac{1}{2} \mathrm{hr}$. After incubation different concentration of the extracts were added serially under liquid paraff in wax and again it was incubated for 6 hours at $37^{\circ} \mathrm{C}$ in a thermo-stated water bath. Further, the liquid paraff in wax was removed with a Pasteur pipette and the resultant mixture was fixed by the addition of $3 \mathrm{ml}$ of $5 \%$ v/v buffered formalin (Cyril-Olutayo et al., 2009).

Counting of cells: the fixed cells were centrifuged at 4000 rpm for 15 minutes and the supernatants were decanted with a capillary tube. Slides were prepared from fixed cells after the process of centrifugation and were observed under a high power objective (x40 and x100) of Research Trinocular Microscope (LABOMED VISION 200o) about four hundred (40o) cells (both sickled and normal erythrocytes) were counted and the percentage sickled cells were recorded (Cyril-Olutayo et al., 2009).

\section{Results:}

Qulitative phytochemical analysis of Carica papaya L.: the results of the qualitative analysis of C.papaya L. are presented in (Table-2).

Table 1:- Phytochemical constituents of different extracts of the leaves, seeds and stems of Carica papaya $\mathrm{L}$.

\begin{tabular}{|c|c|c|c|c|c|c|c|c|c|c|c|c|c|c|}
\hline \multirow[t]{2}{*}{ Components } & \multicolumn{3}{|c|}{ Ethanolic } & \multicolumn{4}{|c|}{ Methanolic } & \multicolumn{4}{|c|}{ Choloroform } & \multicolumn{3}{|c|}{ Petro. ether } \\
\hline & 1 & 2 & 3 & 1 & 2 & & 3 & 1 & & 2 & 3 & 1 & 2 & 3 \\
\hline Tanins & + & + & + & + & - & & + & + & & - & + & + & - & + \\
\hline Saponins & + & + & + & + & + & + & + & + & & + & + & + & + & + \\
\hline Red. Sugars & + & + & + & + & + & + & + & + & & - & + & + & - & + \\
\hline Alkaloids & + & + & + & t & + & + & + & - & & + & + & + & - & + \\
\hline Terpinoids & + & + & + & - & - & & + & + & & + & + & + & + & + \\
\hline Flavonoids & + & + & + & + & + & + & + & + & & + & + & + & + & + \\
\hline Cardiac Glyc. & + & + & + & 7 & & + & - & + & & + & + & - & + & + \\
\hline Anthro quinon & $1-$ & + & + & - & & + & + & - & & + & + & - & + & + \\
\hline Phenols & + & + & + & + & & + & + & + & & + & + & + & + & + \\
\hline
\end{tabular}

Key: $\mathbf{1}=$ Leaves; $\mathbf{2}=$ Seeds; $\mathbf{3}=$ Stem; + (Positive $) ;-($ Negative $)$

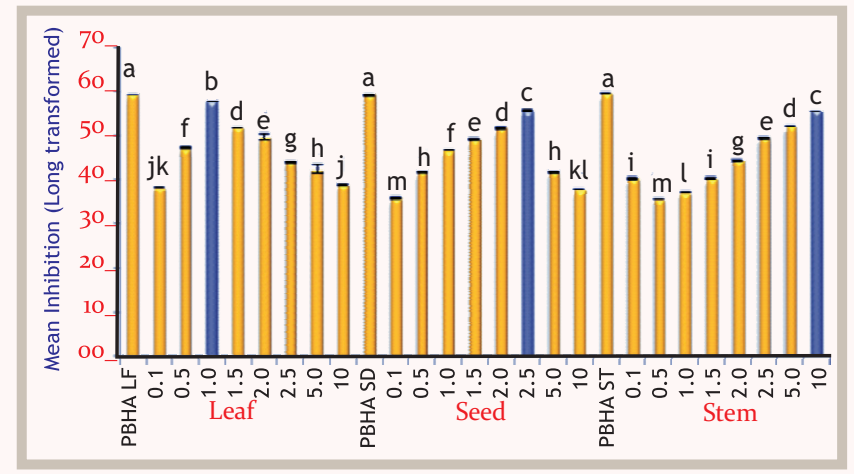

Figure 1: Difference in Means \pm SE Inhibition of sickle cell in vitro at various concentration of C.papaya's Leaf, Seed \& Stem extracts Bar having similar alphabets do not differ from each other at $\mathrm{p}<0.05$ (Based on Duncan's multiple-range test).

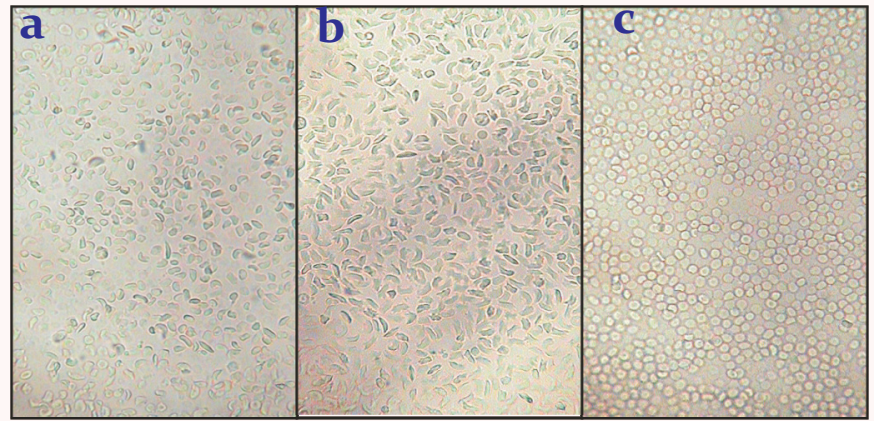

Plate-1: Morphology of drepanocytes of the HbSS blood (a) nontreated; (b) treated with Phosphate buffer saline (PBS Negative control); (c) treated with Parahydroxy benzoic acid (PHB as Positive control).

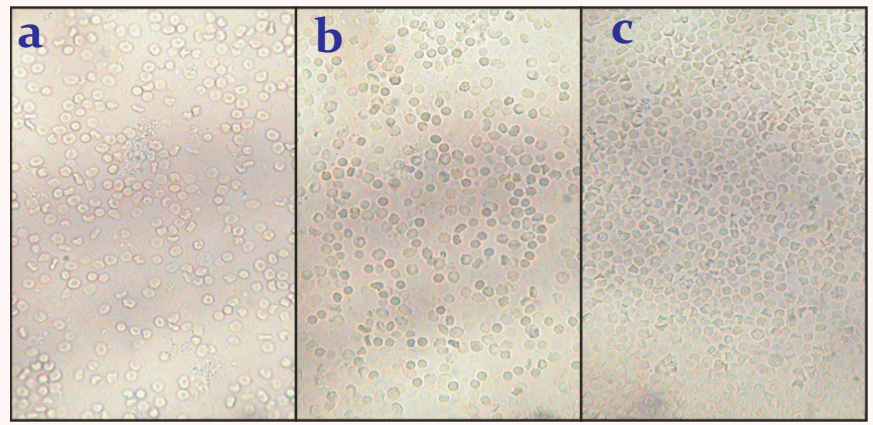

Plate-2: Morphology of drepanocytes of the HbSS blood treated with carica papaya L. shows inhibition effect on Leaf extract (a) (10. o mg/ml) Seed extract (b) (10. o mg/ml) stem extract (c) (10. o mg/ml) extract concentration.

Antisickling activity Inhibition of erythrocyte activity of C.papaya L.: the inhibitory activities found in increasing percentage in Leaves, Seeds and Stems (Fig.-1). The inhibitory activities for different concentrations of extracts revealed maximum inhibition activity (IA) of $71.80 \%$ in C.papaya leaves in a concentration of $1.0 \mathrm{mg} / \mathrm{ml}$; seeds showed a IA of $68.50 \%$ in a concentration of 2.5 $\mathrm{mg} / \mathrm{ml}$; while the stems showed a IA of $68.33 \%$ in a concentration of $10.0 \mathrm{mg} / \mathrm{ml}$. Morphology of drepanocytes (Sickle cells) of the HbSS blood of nontreated, treated with PBS (-ve control), PHBA (+ve control) and different concentration of the extracts of the leaves, seeds and stem extract of C. papaya L. were presented on (Plate-2\&3).

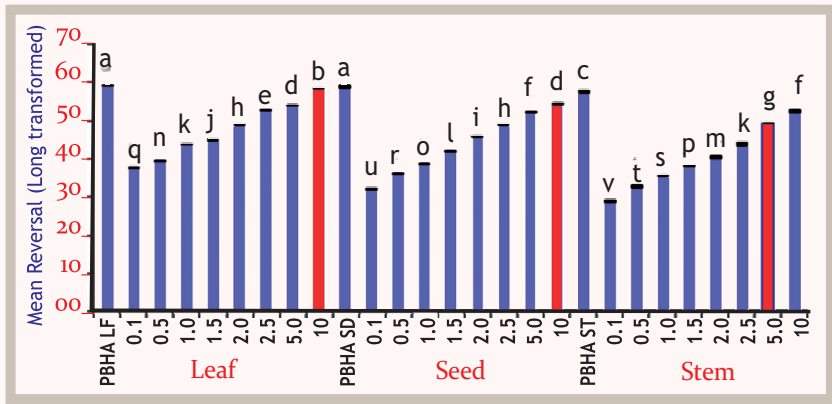

Figure 2: Difference in Means \pm SE Reversal of sickle cell in vitro at difference concentration of C.papaya's Leaf, Seed \& Stem extracts Bar having similar alphabets do not differ from each other at $\mathrm{p}<0.05$ (Based on Duncan's multiple-range test). 


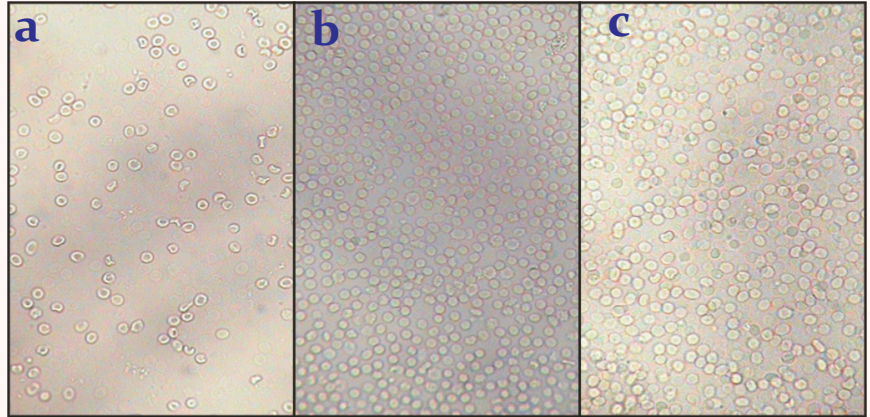

Plate-3: Morphology of drepanocytes of the HbSS blood treated with carica papaya L. shows reversal effect on Leaf extract (a) $(1.0 \mathrm{mg} / \mathrm{ml})$ Seed extract (b) $(2.5 \mathrm{mg} / \mathrm{ml})$ stem extract (c) (10. o $\mathrm{mg} / \mathrm{ml}$ ) extract concentration.

Reversal of Sickled Erythrocyte activity of C.papaya L.: the reversal activities found in increasing percentage in Leaves, Seeds and Stems (Fig.-2). The Reversal of sickled Erythrocyte for different concentrations of extracts revealed maximum reversal activity (RA) of $72.43 \%$ in C.papaya leaves in a concentration of $10.0 \mathrm{mg} / \mathrm{ml}$; seeds showed a RA of $65.96 \%$ in a concentration of $10.0 \mathrm{mg} / \mathrm{ml}$; while the stems showed a RA of $62.97 \%$ in a concentration of $10.0 \mathrm{mg} / \mathrm{ml}$. Morphology of drepanocytes (Sickle cells) of the HbSS blood treated with different concentration of the extracts of the leaves, seeds and stem extract of $C$. papaya $\mathrm{L}$. were presented on (Plate-3).

\section{Discussion:}

phytochemical results from leaves of Carica papaya L. showed most of the positive reactions for flavonoids, phenols, and alkaloids. Tannins and saponins were also positive for most of the parts studied. It is clear from the obtained results on antisickling assay, that maximum antisickling/reversal activity were shown by the parts containing high percentages of phenols and alkaloids. Hence, the management of SCD could be sought in the numerous methods which could prevent polymerization of erythrocytes into sickle cells. The haemoglobin molecule was found to resist polymerization and changing its shape into a sickle by all or in association of one of the following conditions- (i) the propensity and proficiency of the biomolecule to bind to the deoxygenated haemoglobin molecules (Abdulmalik et al., 2005; Bianchi et al., 2009) (ii) alteration of amino acids which are responsible for the quaternary structures of haemoglobin molecules including their active and contact sites (Oyewole et al., 2008) (iii) offer consistency and stability to the haemoglobin molecule (Oyewole et al., 2008; Ibraheem et al., 2010; Chikezie, 2011). Therefore, antioxidants present in the antisickling agents are essential and important as they are capable of attaining one or all of the above-mentioned conditions. Furthermore, the results attained in these phytochemical and antisickling assays can provide important data towards the classification of extracts according to their total phytochemical content and antisickling potential; for different individual parts viz., leaves, stem, and seeds. The results further support the view that phytochemicals with antioxidant properties can well act as potential antisickling agents.

\section{Acknowledgment:}

We are thankful to Dr. Rekha Pandey, Principal, Govt. DB Girls' PG College Raipur for providing necessary research facilities and encouragement. We sincerely thank the University Grants Commission, UGC-CRO, Bhopal, for financial assistance in the form of various minor research projects sanctioned to the Zoology Department of Govt. DB Girls' PG College Raipur..

\section{References:}

Abdulmalik, O., Safo, M.K., Chen, Q., Yang, J., Brugnara, C., Ohene-Frempong, K., Abraham, D. J. \& Asakura, T. (2005): 5hydroxymethyl-2-furfural modifies intracellular sickle hemoglobin and inhibits sickling of red blood cells. $\underline{B r}$. J. Haematol., 128(4):552-561.

Adejumo, O.E., Kolapo, A.L., Roleola, O.P. \& Kasim, L.S. (2010): In Vitro antisickling activities and phytochemical evolution of Plumbago zeylanica and Uvaria chamae. Afr. J. Biotechnol., 9(53):9032-9036.

Adejumo, O.E., Owa-Agbanah, I.S., Kolapo, A.L. \& Ayoola, M.D. (2011): Phytochemical and antisickling activities of Entandro phragma utile, Chenopodium ambrosioides and Petiveria alliacea.J. Med. Plants Res., 5(9):1531-1535.

Alabdallat, N.G. (2016): In vitro Antisickling Activity of Achillea fragrantissima (Forssk) Sch. Bip (Qaysûm) Methanolic Extract on Sickle Cell Disease. Int. J.Pharm. Sci., 38(2):248251.

Alphonsine, R.T., Tibiri, A., Ouedraogo, M., Oudraogo, S., Nacoulma, O.G. \& Guissou, I.P. (2014): Study of antisickling and vasorelaxant activities and acute toxicity assessment of crude extracts of leaves of Ficus sycomorus L. (Moraceae). Pak.J. Biol.Sci., 17(6):829-835.

Amujoyegbe, O.O., Agbedahunsi, J.M. \& Akanmu, M.A. (2014): Antisickling properties of two Calliandra Species: C.portoricensis and C.haematocephala (Fabaceae). Eur. J. Med. Plants. 4(2):206-219.

Avaligbe, C.T., Gbenou, J.D., Kpoviessi, D.S.S., Kpovissi, G.C., Moudachirou, M. \& Georges C. (2012): Antihemolytic Properties of Extracts of six plants used in the Traditional Treatment of sickle cell disease in Benin. L. App. Pharm. Sci., 2(03):08-13.

Bianchi, N., Zuccato, C., Lampronti, I., Borgatti, M. \& Gambari, R. (2009): Fetal Hemoglobin Inducers from the Natural World: A novel approach for identification of drugs for the treatment of p-thalassemia and sickle-cell Anemia. Evidbased Compl. Alt. Med., 6(2):141-151.

Brugnara, C., Franceshi, de.L. \& Alper, S.L. (1993): Inhibition of $\mathrm{Ca}_{2}+$ dependent $\mathrm{K}+$ transport and cell dehydration in sickle erythryocytes by clotrimazole and other imidazole derivatives. J. Clin. Invest., 92(1):520-526.

Chikezie, P.C., Chikezie, C.M. \& Amaragbulem, P.I. (2011): Polymerization of human sickle cell haemoglobin ( $\mathrm{HbS})$ in the presence of three antimalarial drugs. Afr. J. Biochem. Res., 5(2):39-42. 


\section{ORIGINAL ARTICLE}

Chopda, M., Mahajan, N., Chaudhari, S., Pingale, S., Mahajan, P. \& Pawara, V. (2017): Inhibition of erythrocyte sickling in vitro by aqueous extracts of sphaeranthus indicus flowers and Ziziphus jujuba root. Int J.Appl. Res., 2394-5869.

Cyril-Olutayo, C.M., Elujoba, A.A. \& Alani, D.M.(2009): Antisickling properties of the fermented mixture of Carica papaya Linn and Sorghum bicolor (L.) Moench. Afr. J. Pharm. Pharmacol., 3(4):140-143.

Egunyomi, A., Moody, J.O. \& Eletu, O.M. (2009): Antisickling activities of two ethnomedicinal plant recipes used for the management of sickle cell anaemia in Ibadan Nigeria. Afr. J. Biotechnol., 8(1):020-025.

Gbadamosi, I.T., Adeyemi, S B, Adeyemi, A.A. \& Moody, J.O. (2012): In vitro antisickling activities of two indigenenous plants recipes in Ibadan Nigeria. Int. J. Phytomed., 4:205-211.

Harborne, J.B. (1973): Phytochemical methods. Pub. by: Chapman and Hall Ltd. London. pp. 49-188.

Hartwell, L.H., Hood, L., Golgery, M.L., Reynolds, A.E., Silver, L.M. \& Veres, R.C. (2000): Genetics: From Genes to Genomes. 1st ed. Pub. by: Mc Graw-Hill companies. New York. pp.-514-521.

Ibraheem, N. K., Ahmed, J.H. \& Hassan, M.K. (2010): The effect of fixed oil and water of Nigella sativa on sickle cells on in vitro study. Singap.Med. J., 51(3):230-4.

Ibrahim, H., Sani, F.S., Danladi, B.H. \& Ahmadu, A.A. (2007): Phytochemical and antisickling studies of the leaves of Hymenocardia acida Tul (Euphorbiaceae). Pak. J. Biol Sci., 10(5):788-91.

Iyamu, E.W., Turner, E.A., \& Asakura, T. (2003): Niprisan (Nixo699) improves the survival rates of transgenic sickle cell mice under acute severe hypoxic conditions. Br. J. Haematol.., 122 (6): 1001-1008.

Koch, A,A., Yang, Q. \& Olney, R.S. (200o): Sickle hemoglobin allele and Sickle Cell Disease. Am. J. Epidemiol., 151(9): 839-845.

Meselhy, K.M., Hammad, L.N. \& Farag, N. (2012): Novel antisickling, antioxidant and cytotoxic prenylated flavanoids from the bark of Morus alba (L). Life Sci.J., 9(3):830-841.

Mpiana, P.T., Lombe, B.K., Ombeni, A.M., Ngbolua, K.T.N., Tshibangu, D.S.T., Wimba, L.K., Tshilanda, D.D., Mushagalusa, F.K. \& Muyisa, S.K. (2013): In vitro sickling inhibitory effects and anti-sickle erythrocytes hemolysis of Dicliptera colorata C.B. Clarke, Euphorbia hirta L. and Sorghum bicolor (L.) Moench. Open J. Blood Dis., 3(1):43-48.

Mpiana, P.T., Bokota, M.T., Ndjele, M.B.L., Mudogo, V., Tshibangu, D.S.T., Ngbolua, K.N., Atibu. E.K., Kwembe. J.T.K. \& Makele. L.K. (2010): Antisicling activity of three spesies of Justica from Kisangani (DR.Cango) J.tenella, J.gendarussa, and J. Insularis. Int. J. Biol. Chem. Sci., 4(6):1953-1961.

Mpiana, P.T., Misakabu, F.M., Yuma, P.M., Tshibangu, D.S.T., Ngbolua, K.N., Mwanyishay, C.L., Misengabu, N.M., Gbolo, Z.B. \& Kayembe, J.S. (2014): Antisickling activity and physicochemical stability of anthocyanin extracts from Ipomoea batatas leaves. J. Life Med., 2(1):25-31.

Mpiana, P.T., Ngbolua, K.N., Mudogo, V., Tshibangu, D. S. T., Atibu, E.K., Tshilanda, D.D., \& Misengabu, N.M. (2011): Antisickle erythrocytes heamolysis properties and inhibitory effect of Anthocyanins extracts of Trema orientalis (Ulmaceae) on the aggregation of human deoxyhemoglobin S
Ambient Science, 2019: Vol. 06h(1); 11-15 DOI:10.21276/ambi.2019.06h.1.0a02

in vitro. L. Med. Sci., 3(11):129-137.

Naiho, A.O., Okonkwor, B.C. \& Okoukwu, C. (2015): Anti-sickling and membrane stabilizing effects of Carica papaya leaf extract. Br.J. Med. Med. Res., 6(5): 484- 492.

Nwaichi, E.O., Monago, C.C. \& Amaraegbulem, P.I. (2013): Effects of Anthrospora platensis, Monodora myristica and Helianthous annus on the rate of polymerization sickle cell reversion and oxygen affinity of sickle cell Heamoglobin. $L$. Pharma. Sci. Innov., 2(4):05-08.

Nwaoguikpe, R.N., Ujowundu, C.O., Igwe, C.U. \& Dike, P.N. (2015): The effects of Moringa oleifera leaves extracts on sickle cell hemoglobin. J. Sci. Res. Reports., 4(2):123-132.

Nwaoguikpe, R.N., Ujowundu, C.O. \& Okwu, G.N. (2013): The Antisickling Potensial of four curcubits (T.occidentalis, C.maxima, C.sativus, and C.lonatus). Sch. J. Appl. Med. Sci., 1(3): 191-198.

Ogoda, J.O., Akubue, P.I. \& Okide, G.B. (2002): The kinetics of reversal of pre-sickled erythrocytes by the aqueous extract of Cajanus cajan seeds. Phytother. Res., 16(8):1-3.

Ojiako, O.A., Anugweje, K., Igwe, C.U. \& Alisi, C.S. (2012): Evolution of the amino acid profile and heamoglobin polymerization inhibition potensial of some Nigerian Legumes. Br. J. Pharm. Res., 2(2):80-88.

Olufunmilayo, E.A., Adelodun, L.K., Oladimeji, P.R. \& Lateef, S.K. (2010): In vitro antisickling activity and phytochemical evaluation of Plumbago zeylanica and Uvaria chamae. Afr. I. Biotechnol., 9(53): 9032-9036.

Oyewole, O.I., Malomo, S.O., \& Adebayo, J.O. (2008): Comparative studies on anti-sickling properties of thiocyanate, tellurite and hydroxyurea. Pak. J. Med.Sci., 24(1):18-22.

Simeone, E.I., Tufon, E.N., Victor, O.N. \& Noel, N.N. (2012): Antisickling potential of the ethanol seed extracts of Vigna unguiculata and Vigna subterranean. Int. J. Biochem. Biotechnol., 1(9):226-229.

Sofowora, A. (1993): Medicinal plants and Traditional Medicine in Africa. Pub. by: Spectrum Books. Ibadan. pp.10-15.

Trease, G.E. \& Evans, W.C. (1989): Pharmacognosy, 13th Edition. Pub. by: BailliereTindall. London. 882 p.

Tshilanda, D.D., Mpiana, P.T., Onyamboko, D. N.V., Mbala, B.M., Ngbolua, K.T., Tshibangu, D.S.T., Bokolo, M.K., Taba, K.M. \& Kasonga, T.K. (2014): Antisickling activity of butyl stearate isolated from Ocimum basilicum (Lamiaceae). Asian Pac J. Trop. Biomed., 4(5):393-398.

Uwakwe, A.A. \& Nwaoguikpe, R.N. (2008): In vitro antisickling effect of Xylopiaa ethopica and Monodora myrestica. J. Med. Plants Res., 2(6): 119-124.

Vichinsky, E.P. (2002): New therapies in sickle cell disease. Lancet., 360(9333): 629-631. 